\title{
Perspective on the northwestward shift of autumn tropical cyclogenesis locations over the western North Pacific from shifting ENSO
}

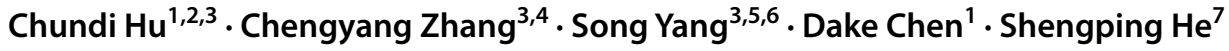

Received: 6 June 2017 / Accepted: 13 November 2017 / Published online: 29 November 2017

(c) The Author(s) 2017. This article is an open access publication

\begin{abstract}
During the recent decades of satellite era, more tropical cyclogenesis locations (TCLs) were observed over the northwestern part of the western North Pacific (WNP), relative to the southeastern part, during the boreal autumn. This increase in TCLs over the northwestern WNP is largely attributed to the synergy of shifting El Niño-Southern Oscillation (ENSO) and the 1998 Pacific climate regime shift. Both central Pacific (CP) La Niña and CP El Niño have occurred more frequently since 1998, with only one eastern Pacific El Niño observed in autumn 2015. The change in the mean longitude of TCLs is closely linked to the ENSO diversity, whereas the change in the mean latitude is dominated by the warming of the WNP induced by an interdecadal tendency of CP La Niña-like events. The physical mechanisms responsible for this shifting ENSO-TCL linkage can be potentially explained by the tacit-and-mutual configurations between tropical upper-tropospheric trough and monsoon trough, on both interannual and interdecadal timescales, which is mainly due to the ENSO-related large-scale environment changes in ocean and atmosphere that modulate the WNP TCL.
\end{abstract}

Keywords Shifting ENSO - Tropical cyclogenesis locations (TCLs) · Tropical upper-tropospheric trough (TUTT) · Monsoon trough (MT) · CP La Niña-like climate regime shift

\section{Introduction}

As a transitional season from the summer monsoon to the winter monsoon, autumn often means a time of crop maturity and harvest in China. Meanwhile, the western North Pacific (WNP) tropical cyclones (TCs) experience an active

Chundi $\mathrm{Hu}$ and Chengyang Zhang contributed equally to the study and are co-first authors.

Electronic supplementary material The online version of this article (https://doi.org/10.1007/s00382-017-4022-1) contains supplementary material, which is available to authorized users.

Song Yang

yangsong3@mail.sysu.edu.cn

1 State Key Laboratory of Satellite Ocean Environment Dynamics, Second Institute of Oceanography, Hangzhou, China

2 School of Atmospheric Sciences, Chengdu University of Information Technology, Chengdu, China

3 Institute of Earth Climate and Environment System, Sun Yat-sen University, Guangzhou, China to less-active transition (see Fig. 1 of Hsu et al. 2014 or He et al. 2015). However, the percentage of TC intensification into typhoon during the late TC season (i.e., autumn) is higher than that in the peak TC season (i.e., summer) (Hsu et al. 2014), especially in September (He et al. 2017). For example, many super-typhoons such as Tip (October 1979), Maemi (September 2003), Megi (October 2010), Haiyan (early-November 2013), and Bopha (late-November 2012) were all generated during the late TC season.

In addition, above $80 \%$ of the TCs formed within the WNP monsoon trough (MT), except for those in July and

4 Climate Center, Guangxi Meteorological Bureau, Nanning, China

5 School of Atmospheric Sciences, Sun Yat-sen University, Guangzhou, China

6 Guangdong Province Key Laboratory for Climate Change and Natural Disaster Studies, Sun Yat-sen University, Guangzhou, China

7 Geophysical Institute, University of Bergen, and Bjerknes Center for Climate Research, Bergen, Norway 
August (see Fig. 1 of Molinari and Vollaro 2013). It also should be noted that the mean latitude of WNP tropical cyclogenesis locations (TCLs) was clearly further to the north in summer than in autumn (not shown), mainly due to the distinctly different seasonal climatic backgrounds (e.g., warm pool, monsoon flows, etc.). Thus, we emphasize that it is important to separately study the WNP TC activity during autumn (e.g., Hsu et al. 2014; Zhao et al. 2014a; Zhao and Wang 2016; Choi et al. 2017) and that in summer.

The variability of WNP TC/typhoon activity is strongly affected by the El Niño-Southern Oscillation (ENSO) (e.g., Lander 1994; Chan 2000; Wang and Chan 2002; Camargo and Sobel 2005; Camargo et al. 2007; Zhao et al. 2010; Kim et al. 2011; Wang et al. 2013; Wang and Wu 2016) and the Pacific Decadal Oscillation (PDO) (e.g., Wang and Liu 2016; Zhao and Wang 2016). Frequent late-season catastrophic super-typhoons thus led us to wonder how the change in the ENSO affects the WNP TCLs during autumn. Because the warming due to greenhouse gases will not only lead to more frequent extreme ENSO (Cai et al. 2014, 2015a, b) and ENSO diversity (e.g., Hu et al. 2016a, b; Chen et al. 2015), but also fewer-but-stronger TCs (e.g., Knutson et al. 2010) since the negative contributions from the reduced $\mathrm{TC}$ frequency and its genesis location-related duration tend to offset the positive contribution from the increasing TC intensity (Lin and Chan 2015). In other words, changes in TCLs and ENSO in the context of global warming may primarily contribute to the change in the frequency of intense typhoons (e.g., Wu and Wang 2008; Wang et al. 2013, Hsu et al. 2014). That is, TCL shift often affects TC intensity via changing the durations over the ocean (i.e., TC has more or less time and distance over the WNP warm pool for developing) (e.g., Wang and Chan 2002; Camargo and Sobel 2005; Wu and Wang 2008; Zhao et al. 2011, 2014b; Wang et al. 2013; Zhao and Wu 2014).

It is well known that the change in sea surface temperature (SST) related to the ENSO shift not only leads to a change in tropical convective activity pattern (e.g., Hu et al. 2016b) and then the remote induction of Rossby waves via the perturbation of upper-level divergence (e.g., Sardeshmukh and Hoskins 1988), but also results in changes of large-range atmospheric and oceanic environments related to TC activity (Gray 1979) such as the Walker circulation, the WNP subtropical high, absolute vorticity, relative humidity, vertical wind shear, vertically-integrated moisture transport, and horizontal distribution of local SST (e.g., Chan 2006; Kim et al. 2011; Zhang et al. 2014; Choi et al. 2015; Wang and $\mathrm{Wu}$ 2016; Huangfu et al. 2017). For example, it has been found by many studies that a southeastward tendency of WNP TCLs in El Niño cases compared to La Niña cases (e.g., Camargo and Sobel 2005; Camargo et al. 2007; Wang et al. 2013; Zhao and Wang 2016) in both warm and cold phases of the PDO (Zhao and Wang 2016).
Existing theories also suggest that the east-west shifts of tropical upper-tropospheric trough (TUTT) and MT may induce changes in WNP TCLs (e.g., Lander 1994; Wu et al. 2012, 2015; Zhao et al. 2014b; Huang et al. 2016; Wang and Wu 2016; Deng et al. 2017; Huangfu et al. 2017) on both interannual and interdecadal timescales. It was ever pointed out that the mean TCL showed a westward shift over the WNP mainly due to (1) the pronounced westward shift of TUTT (Wu et al. 2015) and/or (2) the interdecadal change of the WNP MT (Huangfu et al. 2017). On the other hand, Zhang et al. (2014) demonstrated that southern China had experienced increasing autumn drought due to the ENSO regime shift in the past decades. Given that the East Asia autumn rainfall is closely linked with the WNP TC activity (Wu et al. 2005; Hong et al. 2016), it is doubtful that any shift in ENSO flavor can contribute to the change in autumn WNP TCLs via changing TUTT and/or MT.

Although the interdecadal shift of WNP TCLs since the late-1990s has been widely studied (e.g., Liu and Chan 2013, Hsu et al. 2014; Choi et al. 2015, 2017; He et al. 2015; Hong et al. 2016; Zhao and Wang 2016; Huangfu et al. 2017), these studies focused on the TC/typhoon activity associated with either ENSO phases or combined phases of PDO and ENSO (e.g., Zhao and Wang 2016). The combined effects of TUTT and MT modulated by shifting ENSO (i.e., two types of La Niña and two types of El Niño) on the concurrent WNP TCL change, however, have not been well investigated. Thus, we will demonstrate that the interannual and interdecadal linkages between the WNP TCLs and the tacitand-mutual configurations of TUTT and MT in autumn are closely related to four ENSO flavors and the PDO-like and/ or central Pacific (CP) La Niña-like climate regime shift.

\section{Data and methodology}

The latitude and longitude information of all primary TCLs in autumn is from the WNP best track data from the Joint Typhoon Warming Center (JTWC, https://metoc.ndbc.noaa. gov/web/guest/jtwc/best_tracks/western-pacific) since previous studies (e.g., Wu and Zhao 2012 for details; Zhao and Wang 2016) suggested that the TC data from the JTWC is more reliable than that from the Japan Meteorology Agency (JMA) and the Shanghai Typhoon Institute of China Meteorology Administration (CMA). Only the results obtained from the JTWC data are given in the main body of the paper. But we have verified the results from the JTWC by using the TC datasets from the JMA and CMA, and found the northwestward shift of WNP TCLs was significant and generally in accordance with each other (not shown) albeit with some discrepancy.

According to Zhao and Wang (2016), the possible causes of the uncertainty in three TC datasets are mainly due to 
the different estimate techniques and different computation methods among different agencies (e.g., Emanuel 2005; Song et al. 2010; Wu and Zhao 2012). For instance, the 1-min average wind speed, 10-min average wind speed, and 2-min average wind speed are adopted by JTWC, JMA, and CMA, respectively. Hence some aspects of TC activity are found to be not consistent and even contradictory (e.g., Song et al. 2010; Kamahori et al. 2006; Wu and Zhao 2012; Landsea and Franklin 2013; Zhao et al. 2014a).

Monthly atmospheric variables are obtained from the Interim European Centre for Medium-range Weather Forecasts Reanalysis (ERA-Interim, Dee et al. 2011). Relevant results have been confirmed by using the atmospheric variables from the JRA-55 data (Kobayashi et al. 2015) and the NCEP/NCAR reanalysis data (Kalnay et al. 1996). Thus only the results obtained from the ERA-Interim are shown in this study. The mean of two commonly used SST datasets is employed in this study: the NOAA Extended Reconstructed SST version 4 (Huang et al. 2015; Liu et al. 2015) and the Hadley Centre Global Sea Ice and SST analyses (Rayner et al. 2003). Here, the Hadley SST was interpolated to the same $2^{\circ} \times 2^{\circ}$ grid as the NOAA SST before analysis. The boreal autumn (i.e., September-November, or SON) during 1979-2015 is the season of our focus in this study, and the anomalous field is based on the deviation from the 1979-2015 climatology for each variable.

The Genesis Potential Index (GPI, Emanuel and Nolan 2004) or the improved GPI (Murakami and Wang 2010) is often used to assess large-scale environment of TC genesis since existing studies have suggested that it can capture TC genesis variation well at various time scales (e.g., Camargo et al. 2007, 2009; Jiang et al. 2012; Liu and Chan 2013; Zhao et al. 2015a, b; He et al. 2017; Zhao and Wu 2017). Referring Emanuel and Nolan (2004) and Murakami and Wang (2010), the modified GPI in this study is defined as:

$G P I=\left|10^{5} \eta\right|^{\frac{3}{2}}\left(\frac{R H}{50}\right)^{3}\left(\frac{V_{p o t}}{70}\right)^{3}\left(1+0.1 V_{\text {shear }}\right)^{-2}\left(\frac{-\omega+0.1}{1.0}\right)$,

where $500-\mathrm{hPa}$ vertical $p$-velocity $(\omega)$ is included in the original GPI, $\eta$ is $850-\mathrm{hPa}$ absolute vorticity, $R H$ is $700-\mathrm{hPa}$ relative humidity, $V_{\text {shear }}$ is the magnitude of vertical wind shear between 200 and $850 \mathrm{hPa}, V_{p o t}$ is potential intensity (Emanuel 1995; Bister and Emanuel 2002), which is a function of SST, sea-level pressure, convective available potential energy, atmospheric temperature, humidity, etc. Followup studies further indicated that the enhanced mid-level relative humidity and low-level cyclonic vorticity are the most important factors in modulating the location and frequency of TC genesis (e.g., Camargo et al. 2007, 2009; Jiang et al. 2012; Zhao et al. 2015a, b, 2017; Zhao and Wu 2017).

According to the different definitions of diverse recognition methods for ENSO diversity with a threshold of 0.6 SD
Table 1 Four flavors of ENSO synthetically identified by eight indices (i.e., Niño3.4, Niño3.4b, Niño3b, Niño4b, NCT, NWP, EPI, and CPI) in the boreal autumn during 1979-2015

\begin{tabular}{|c|c|}
\hline ENSO flavor & Year \\
\hline CP La Niña & 1983, 1984, 1988, 1998, 1999, 2000, 2008, 2010, 2011 \\
\hline EP La Niña & 1985, 1995, 2001, 2005, 2007 \\
\hline CP El Niño & $\begin{array}{l}\text { 1986, 1990, 1991, 1994, 2002, 2003, 2004, 2006, } \\
\text { 2009, 2012, } 2014\end{array}$ \\
\hline EP El Niño & 1982, 1987, 1997, 2015 \\
\hline
\end{tabular}

The years after 1998 are boldfaced

[i.e., the EPI and CPI methods (Kao and $\mathrm{Yu}$ 2009; $\mathrm{Yu}$ and Kim 2010), the NCT and NWP methods (Ren and Jin 2011), and the Niño3b and Niño4b methods (Hu et al. 2016a)], as well as the Niño3.4 and Niño3.4b (Hu et al. 2016a), we synthetically identify four eastern Pacific (EP) El Niño autumns (Table 1) and 11 CP El Niño autumns (Table 1). Kim et al. (2009, 2011) and Zhang et al. (2014) classified La Niña events into one category due to less change in the zonal location of La Niña SST cooling (Kug et al. 2009; Ren and Jin 2011). Nevertheless, there were more CP La Niña autumns (Table 1) than EP La Niña autumns (Table 1). Note that there was only one EP El Niño, while there were frequent CP La Niña and CP El Niño, during 1998-2015.

The PDO index is defined as the first principle component of the normalized SST anomalies over the North Pacific $\left(105^{\circ} \mathrm{E}-105^{\circ} \mathrm{W}, 20^{\circ} \mathrm{N}-60^{\circ} \mathrm{N}\right)$ in the boreal autumn during 1979-2015. The vertically-integrated moisture flux (QUV) is computed as follow:

$Q U V=\frac{1}{g} \int_{200}^{p_{s}} q \vec{V} d p$

where $g, p_{s}, q$, and $\vec{V}$ are the acceleration of Earth's gravity, surface pressure, specific humidity, and horizontal wind vector, respectively.

\section{Results}

Since the horizontal SST distribution is a crucial factor for TC activity (e.g., Webster et al. 2005; Choi et al. 2015), to confirm the different spatial features of the four flavors of ENSO identified in Table 1, we first show the associated composite SST anomalies and differences in Fig. 1a-d, e-j, respectively. The spatial patterns in Fig. 1a-d highlight the positions and magnitudes of SST anomalies related to $\mathrm{CP}$ La Niña cooling (CPC), EP La Niña cooling (EPC), CP El Niño warming (CPW), and EP El Niño warming (EPW), respectively.

It is interesting that both the SST warming (in the western Pacific, WP) and cooling (in the CP) during CP La Niña are 

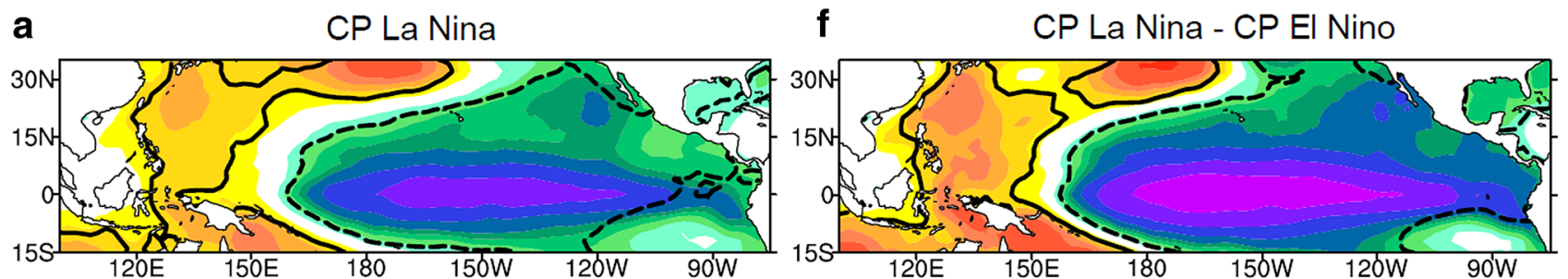

b EP La Nina

$9 \quad$ CP La Nina - EP El Nino

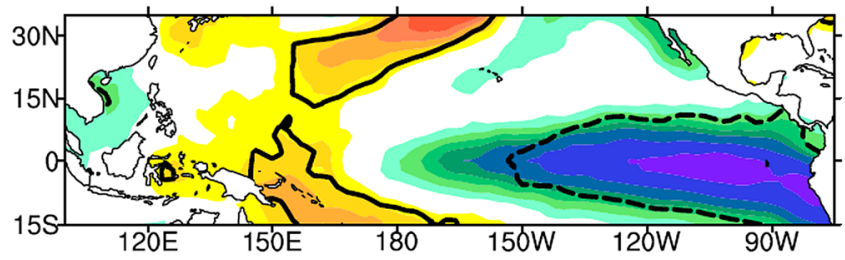

c

CP El Nino

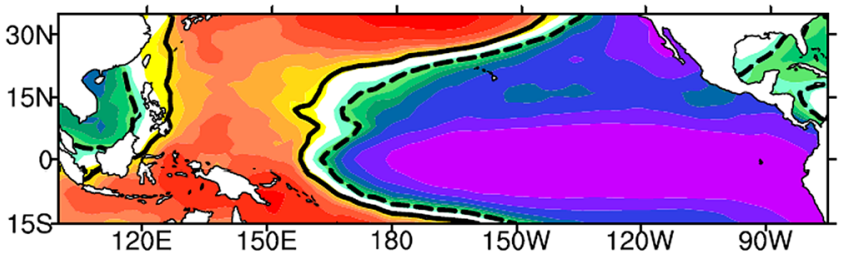

h

EP La Nina - CP El Nino
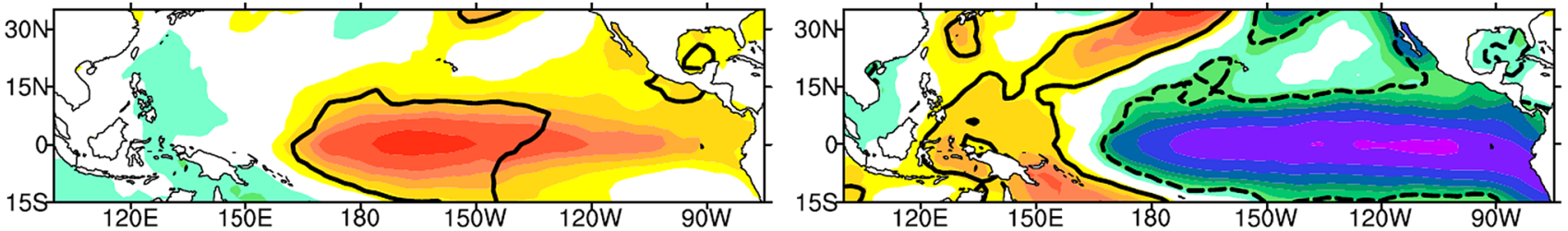

d

EP El Nino

i

EP La Nina - EP El Nino

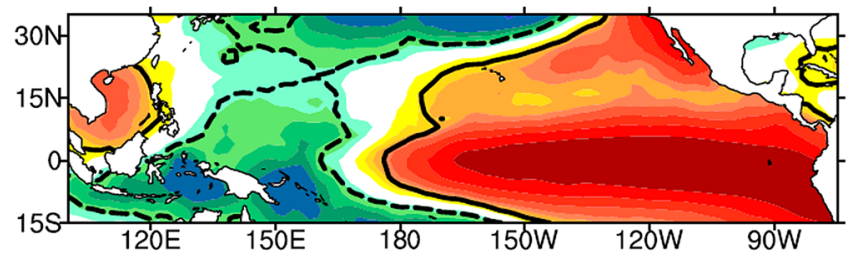

e

CP El Nino - EP EI Nino

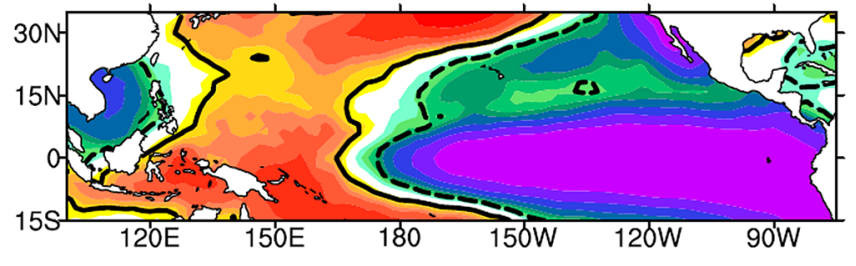

j

CP La Nina - EP La Nina
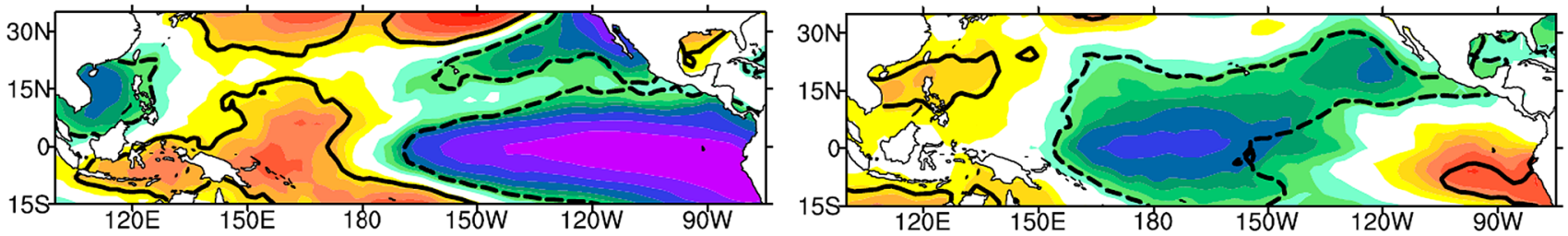

Fig. 1 Composite patterns of SST anomalies (K, black curves for the local SST anomalies exceeding 0.6 SD) in SON for a CP La Niña, b EP La Niña, c CP El Niño, and d EP El Niño years, and its differences for e CP El Niño minus EP El Niño, f CP La Niña minus CP El

Niño, g CP La Niña minus EP El Niño, h EP La Niña minus CP El Niño, i EP La Niña minus EP El Niño, and j CP La Niña minus EP La Niña

stronger than those in EP La Niña (Fig. 1a, b, j), whereas both the SST cooling (in the WP) and warming (in the CP) during CP El Niño are weaker than those in EP El Niño (Fig. 1c-e). Moreover, relative to the CP El Niño, the CP La Niña shows more robust SST anomalies in the EP (Fig. 1a, c). Note that only the difference between CPC and EPC exhibits a Modoki type (Fig. 1j), suggesting that there are no

significant SST anomalies near the coast of South America during both CPC and CPW (Fig. 1a, c), which is consistent with $\mathrm{Hu}$ et al. (2016a).

Although the maximum SST anomaly in CPW is only about half of that in EPW, both the background SST and local El Niño warming $\left(135^{\circ} \mathrm{E}-180^{\circ}\right)$ of $\mathrm{CPW}$ are higher than those of EPW (Fig. 1e), and are more favorable for deep 
convective activity (e.g., Kim et al. 2011; Hu et al. 2016b), providing a favorable environment for movement of TCs toward East Asia (Jin et al. 2013; Wang et al. 2013; Zhao et al. 2014b; Zhao and Wang 2016). Likewise, the slight SST warming over the WNP during La Niña (Fig. 1a, b) is set against the higher background SST in the warm pool where
SST is also warmer than that of the two types of El Niño (Fig. 1f-i), inevitably making it easily conducive to TC formation and intensification (Knutson et al. 1998; Choi et al. 2015), especially for CP La Niña (Fig. 1a, f, g).

In addition to appropriate SST, TCs tend to form in a region with favorable large-scale atmospheric
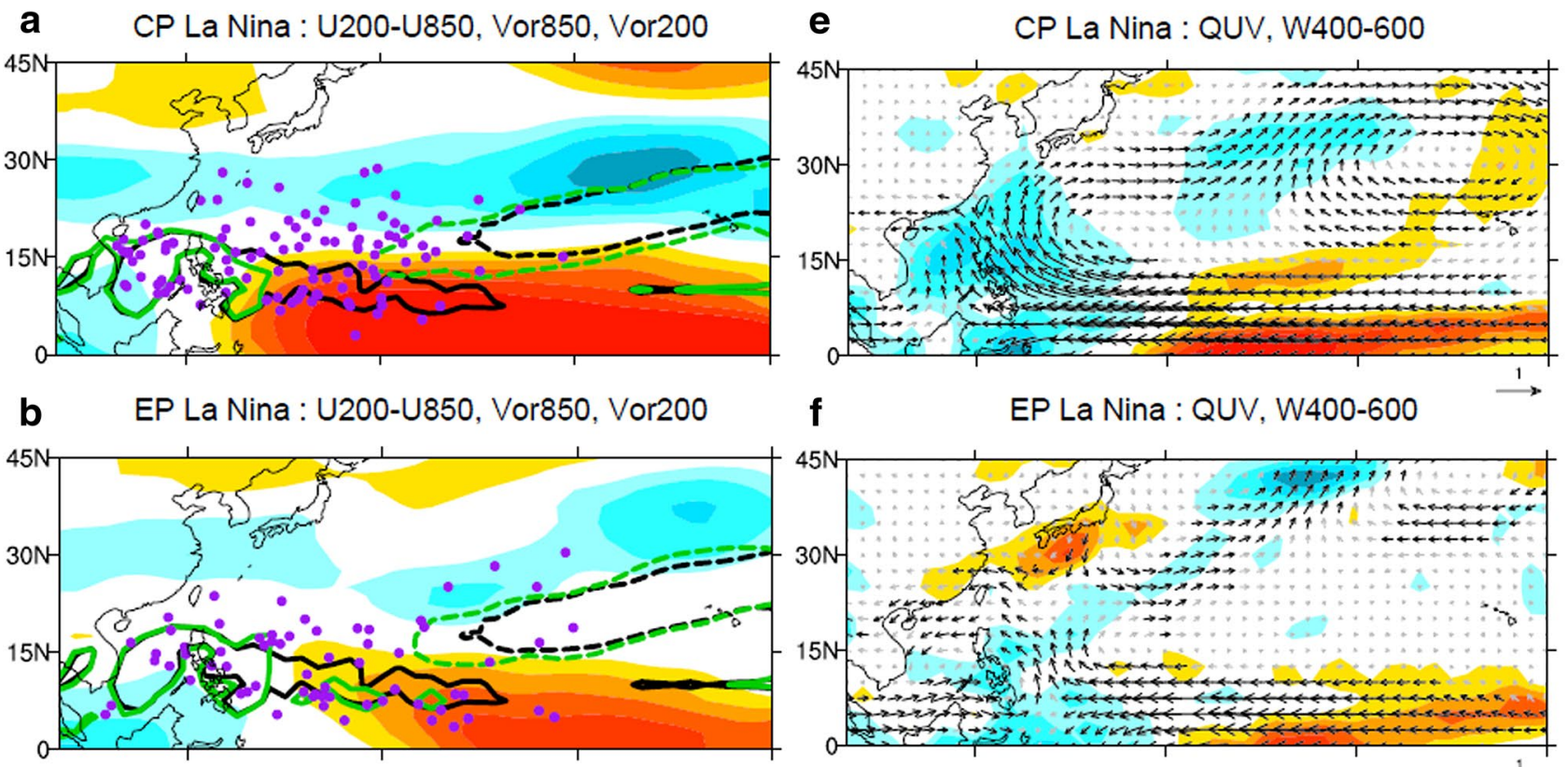

C CP El Nino: U200-U850, Vor850, Vor200
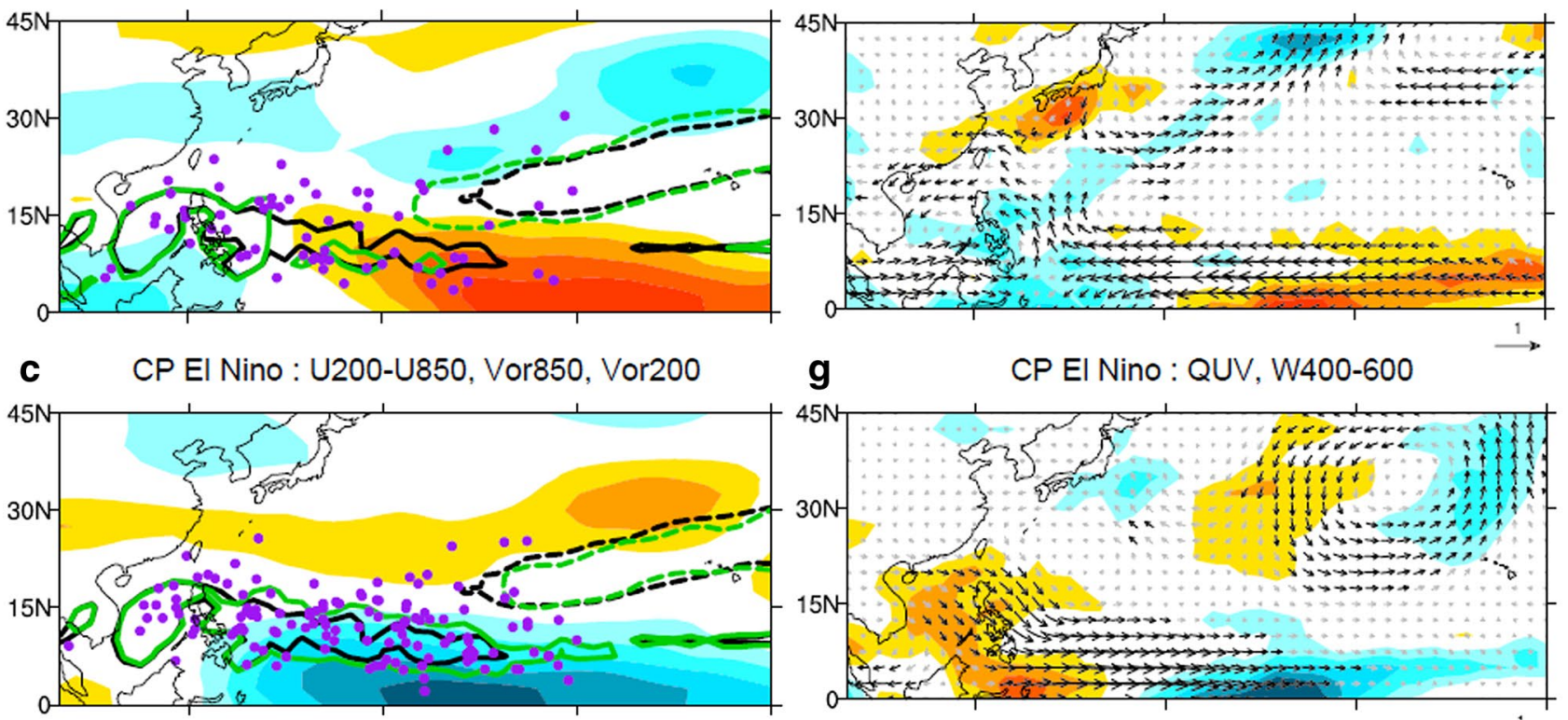

d EP El Nino : U200-U850, Vor850, Vor200

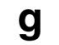

CP El Nino : QUV, W400-600
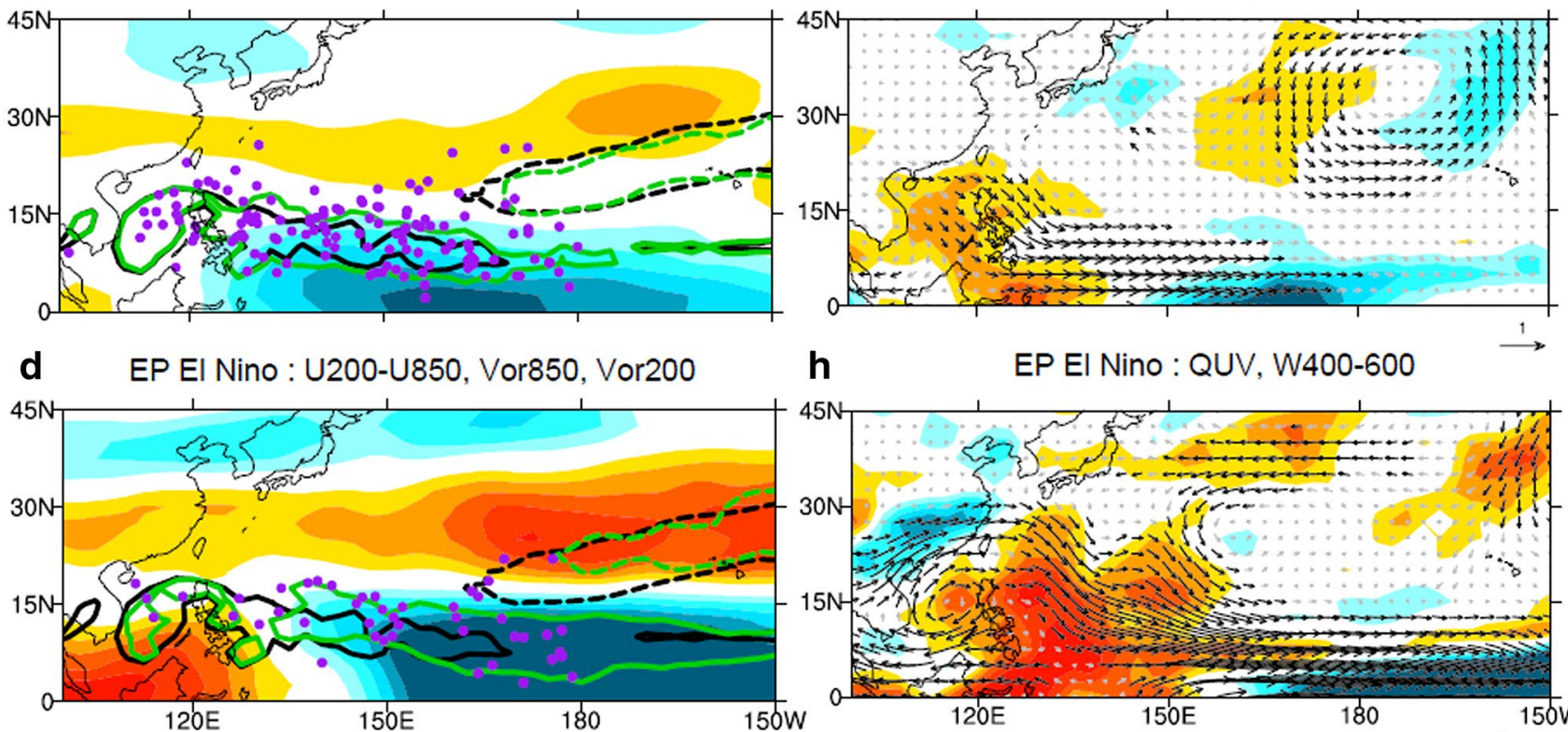

h

EP El Nino : QUV, W400-600
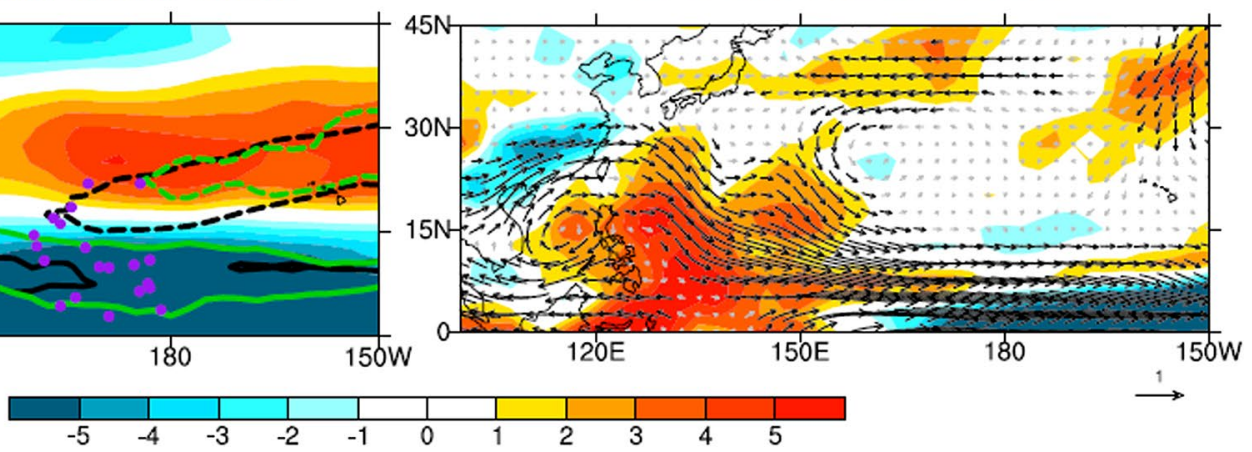

Fig. 2 Composite patterns of (left panels) U-wind vertical shear between 200 and $850 \mathrm{hPa}$ (shading, $\mathrm{m} \mathrm{s}^{-1}$ ), TUTT (green dashed line identified by relative vorticity of $1 \times 10^{-6} \mathrm{~s}^{-1}$ at $200 \mathrm{hPa}$ ), MT (green solid line identified by relative vorticity of $5 \times 10^{-6} \mathrm{~s}^{-1}$ at $850 \mathrm{hPa}$ ), TCLs (purple dots), and (right panels) 400-600 hPa averaged verti- cal $p$-velocity (W400-600, shading, $2.0 \times 10^{-2} \mathrm{~Pa} \mathrm{~s}^{-1}$ ) and verticallyintegrated moisture flux (QUV, vector, $10^{3} \mathrm{~kg} \mathrm{~m}^{-1} \mathrm{~s}^{-1}$ ) for a, e CP La Niña, b, f EP La Niña, c, $\mathbf{g}$ CP El Niño, and $\mathbf{d}, \mathbf{h}$ EP El Niño years. The black dashed and solid lines indicate the climatological TUTT and MT during 1979-2015, respectively 
environments for their intensification. As expected, composite features of boreal autumn TCLs during CPC, EPC, $\mathrm{CPW}$, and EPW events are characterized by different largescale environment changes. As the black dashed lines shown in Fig. 2a-d, the climatological TUTT, also known as the mid-oceanic trough (e.g., Ferreira and Schubert 1999) or the mid-Pacific trough (Deng et al. 2017), often elongates from east-northeast to west-southwest over the tropical oceans. According to Wang and Wu (2016), the WNP TCs often occur to the west of TUTT, mostly over the region of $115^{\circ} \mathrm{E}-160^{\circ} \mathrm{E}, 0^{\circ}-20^{\circ} \mathrm{N}$, due to the strong vertical wind shear to the southeast of the trough (e.g., Kelley and Mock 1982; Fitzpatrick et al. 1995).

During the years of the two types of La Niña, the lowlevel easterly trade wind intensifies, with a northwestward retreat of the MT and weakened tropical convection as well as GPI to the east of the MT (Fig. 2a, b, e, f, Fig. A1a, A1c in the supplementary). Meanwhile, the upper-level TUTT expands southwestward; together, they result in a large positive vertical wind shear on the south side of the TUTT, which is just over the tropical disturbances in the tropical WNP region (Fig. 2a, b), and subdues tropical cyclogenesis over the southeastern WNP, consistent with Wu et al. (2015). Moreover, the westward retreat of the MT (Fig. 2a, b) coincides with the warming WNP associated with the two types of La Niña cooling (Fig. 1a, b), weakening subtropical vertical wind shear to the north of $17^{\circ} \mathrm{N}$ or so, enhancing convection (i.e., vertical ascending motion), moisture transport over the northwestern WNP (Fig. 2e, f), and positive GPI anomalies over the western part of WNP (Fig. A1a), which are favorable for local TC genesis.

Note that the WNP warming related to CPC (Fig. 1a) is more robust than that related to EPC (Fig. 1b). In addition, the whole change in large-scale environment (i.e., SST, TUTT, MT, vertical wind shear, convection, moisture transport, and GPI) during CPC years (Figs. 1a, 2a, e; Fig. A1a) are similar to, but are clearly stronger and more westward than, those of the EPC years (Figs. 1b, 2b, f; Fig. A1c). Thus, the mean latitude (longitude) of WNP TCLs during CPC is more northward (westward) than that during EPC (Fig. A2). Therefore, the shifting La Niña is not only responsible for the change in the mean longitude of WNP TCLs but also for the mean latitude.

In contrast, the large-scale environments associated with the two types of El Niño are apparently different. It is consistent with Wang and $\mathrm{Wu}$ (2016) that all the TUTT eastretreat years can be identified as El Niño years. Besides, the WNP MT experiences a southeastward expansion (Fig. 2c, d) since the low-level easterly trade weakens, with strengthened deep convection and GPI to the east of the climatological MT (Fig. 2g, h; Fig. A1b, A1d). Meanwhile, the upper-level TUTT retreats northeastward; together, they result in large negative westerly vertical wind shear over the southeastern
WNP, particularly for EPW years (Fig. 2c, d), and favor local tropical cyclogenesis. Moreover, the strengthening subtropical westerly wind shear plays an important role in inhibiting $\mathrm{TC}$ formation to the north of $17^{\circ} \mathrm{N}$ (Fig. 2c, d). In addition, the anomalous convection (i.e., vertical descending motion), moisture transport, and GPI over the WNP (Fig. 2g, h; Fig. A1b, A1d) are almost opposite to those of La Niña years (Fig. 2e, f; Fig. A1a, A1c), unfavorable for TC formation over the northwestern WNP, especially during EPW years.

Note also that the overall changes in large-scale environment (i.e., TUTT, MT, vertical wind shear, convection, moisture transport, and GPI) during CPW years (Fig. 2c, g; Fig. A1b) are similar to, but obviously weaker and more westward than, those of EPW years (Fig. 2d, h; Fig. A1d) mainly due to the distinct zonal position of maximum SST anomalies between CP El Niño and EP El Niño. Thus, the mean longitude of the WNP TCLs during CPW is more westward (eastward) than that during EPW (La Niña) (Fig. A2). However, there is smaller difference in the mean latitude of the WNP TCLs between the CPW and EPW composites (Fig. A2), while the difference between the two types of El Niño and La Niña composites is much larger (Fig. A2). In addition, the mean latitude anomalies (Fig. 3a) are positive in two EPW years of 1982 and 2015, but are negative in the other two EPW years of 1987 and 1997. Hence, the shifting El Niño is only responsible for the change in the mean longitude of the WNP TCLs but generally not the mean latitude.

We also noted that both the mean latitude and longitude of the WNP TCLs coincidently reflected remarkable interdecadal changes in autumn 1998 (Fig. 3a, b). Specifically, the mean TCLs shifted northward by $2^{\circ}$ of latitude and westward by $8^{\circ}$ of longitude or so (Fig. 3c, d, green bars), re-confirming that more and more TCs form over the northwestern WNP since 1998 (Fig. A3) from another angle, which is consistent with previous studies (e.g., Hsu et al. 2014; Choi et al. 2015, 2017; He et al. 2015; Hong et al. 2016; Zhao and Wang 2016; Huangfu et al. 2017).

Moreover, there are significant interdecadal changes in the relationship between PDO and TCLs (Table 2), as well as between PDO and diverse ENSO indices (Table 2), with strongly enhanced correlations since the late-1990s except for EPI. Such interdecadal changes in TCLs are also closely linked to the interdecadal change in ENSO years (Fig. 3c, d; Table 2), confirming that the TCL interdecadal variability is closely linked to the late-1990s interdecadal change in the correlation between PDO and ENSO (e.g., Jo et al. 2015; Hu et al. 2016a; Zhao and Wang 2016) and the resultant western Pacific interdecadal warming (Fig. 4a-b; Fig. A4).

To further investigate and confirm the large-scale environment changes associated with the 1998 TCL interdecadal change, we analyzed the relevant patterns of autumn SST, vertically-integrated moisture transport, U200-U850, TUTT and MT (Fig. 4a-d). Over the WNP and the central 

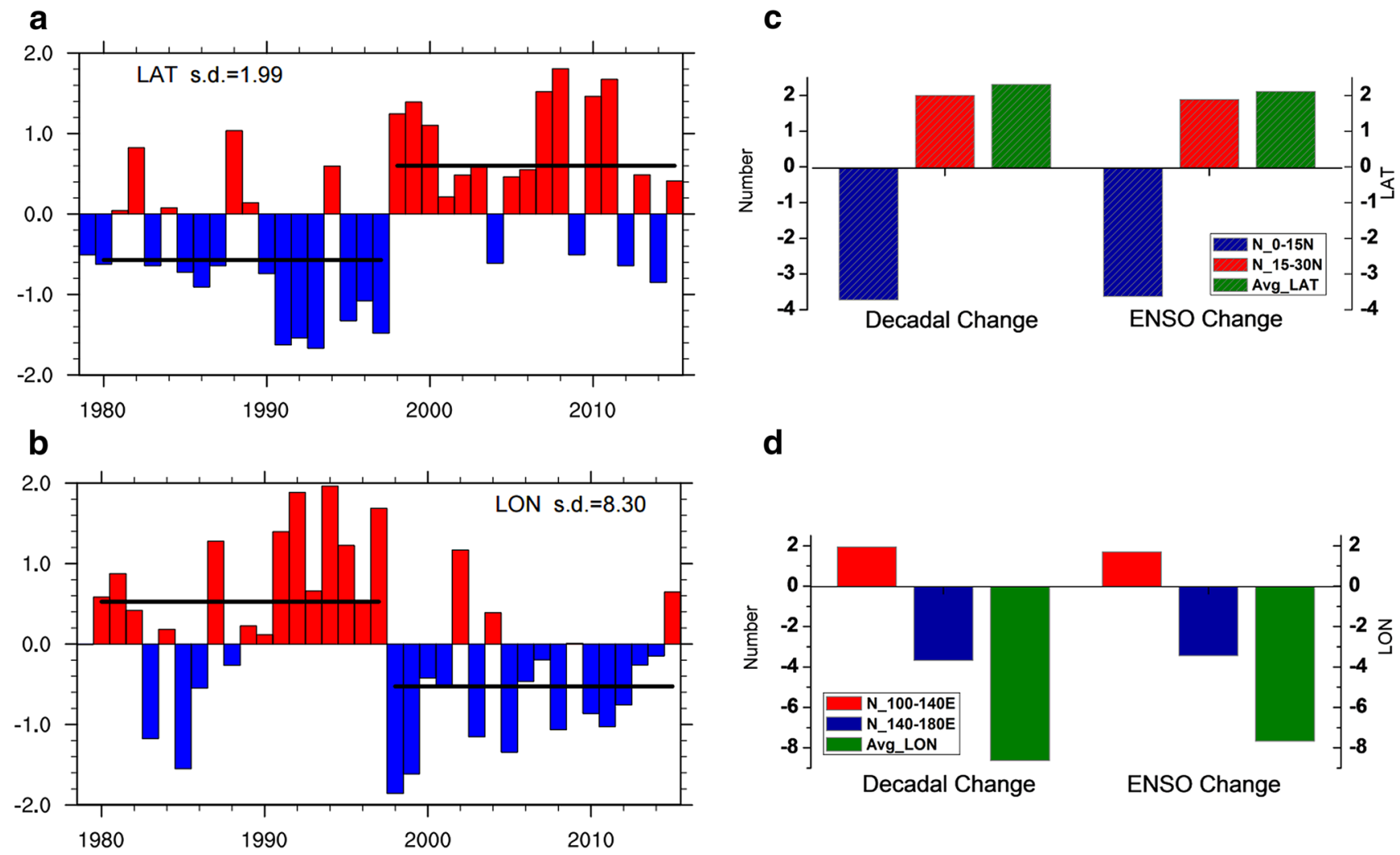

Fig. 3 Normalized time series of a latitude (LAT) and b longitude (LON) of the mean tropical cyclogenesis location over $100^{\circ} \mathrm{E}-180^{\circ} / 0^{\circ}-30^{\circ} \mathrm{N}$ in autumn during $1979-2015$. Decadal changes and ENSO-related decadal changes in $\mathbf{c}$ numbers (blue for $0^{\circ}-15^{\circ} \mathrm{N}$,

red for $15^{\circ} \mathrm{N}-30^{\circ} \mathrm{N}$ ) and averaged latitudes (green), and in $\mathbf{d}$ numbers (red for $100^{\circ} \mathrm{E}-140^{\circ} \mathrm{E}$, blue for $140^{\circ} \mathrm{N}-180^{\circ}$ ) and averaged longitudes (green) of SON WNP tropical cyclogenesis between 1998-2015 and 1980-1997 (1998-2015 minus 1980-1997)

Table 2 Correlation matrixes of PDO index and other indices (i.e., LAT, LON, Niño3.4, Niño3.4b, Niño3b, Niño4b, NCT, NWP, EPI, and CPI) in the boreal autumn during 1979-2015 (79-15), 1979-1997 (79-97) and 1998-2015 (98-15), respectively

\begin{tabular}{|c|c|c|c|c|c|c|c|c|c|c|}
\hline PDO & LAT & LON & Niño3.4 & Niño3.4b & Niño3b & Niño4b & NCT & NWP & EPI & CPI \\
\hline $79-15$ & -0.77 & 0.60 & 0.55 & 0.58 & 0.55 & 0.25 & 0.51 & 0.31 & 0.31 & 0.40 \\
\hline 79-97 & -0.58 & 0.11 & 0.37 & 0.37 & 0.40 & 0.06 & 0.35 & 0.05 & 0.31 & 0.18 \\
\hline $98-15$ & -0.68 & 0.70 & 0.87 & 0.90 & 0.84 & 0.85 & 0.83 & 0.72 & 0.21 & 0.76 \\
\hline
\end{tabular}

|Correlationl $>0.5$ is boldfaced

North Pacific, the mean SST has significantly increased since 1998, together with a robust cooling over the central tropical Pacific (Fig. 4a, b), which is generally considered to be related to the late-1990s' Pacific decadal variability (e.g., Wang et al. 2013, Hsu et al. 2014; He et al. 2015; Hu et al. 2016a; Hong et al. 2014, 2016; Zhao and Wang 2016). Moreover, the patterns of ENSO-related decadal difference (Fig. 4c; Fig. A4a) are also very similar to the total decadal changes (Fig. 4d; Fig. A4b), with a shape related to PDO-like and CP La Niña-like backgrounds, which might be responsible for the interdecadal changes of the WNP TC activity (e.g., Hsu et al. 2014; He et al. 2015; Hong et al. 2016; Zhao and Wang 2016).
Besides, the corresponding decadal difference patterns of U200-U850, TUTT and MT (Fig. 4c, d) also mirror the CP La Niña composite patterns (Fig. 2a), which further highlight the enhanced vertical wind shears over the central tropical Pacific, the northwestward retreated MT and the southwestward expanded TUTT. These unfavorable dynamic conditions for local TC genesis shed lights on that the interdecadal northwestward shift of the WNP TCLs is closely linked to the PDO-like and/or CP La Niña-like climate regime shift (e.g., Wang et al. 2013, Hsu et al. 2014; He et al. 2015; Hong et al. 2016; Zhao and Wang 2016). 

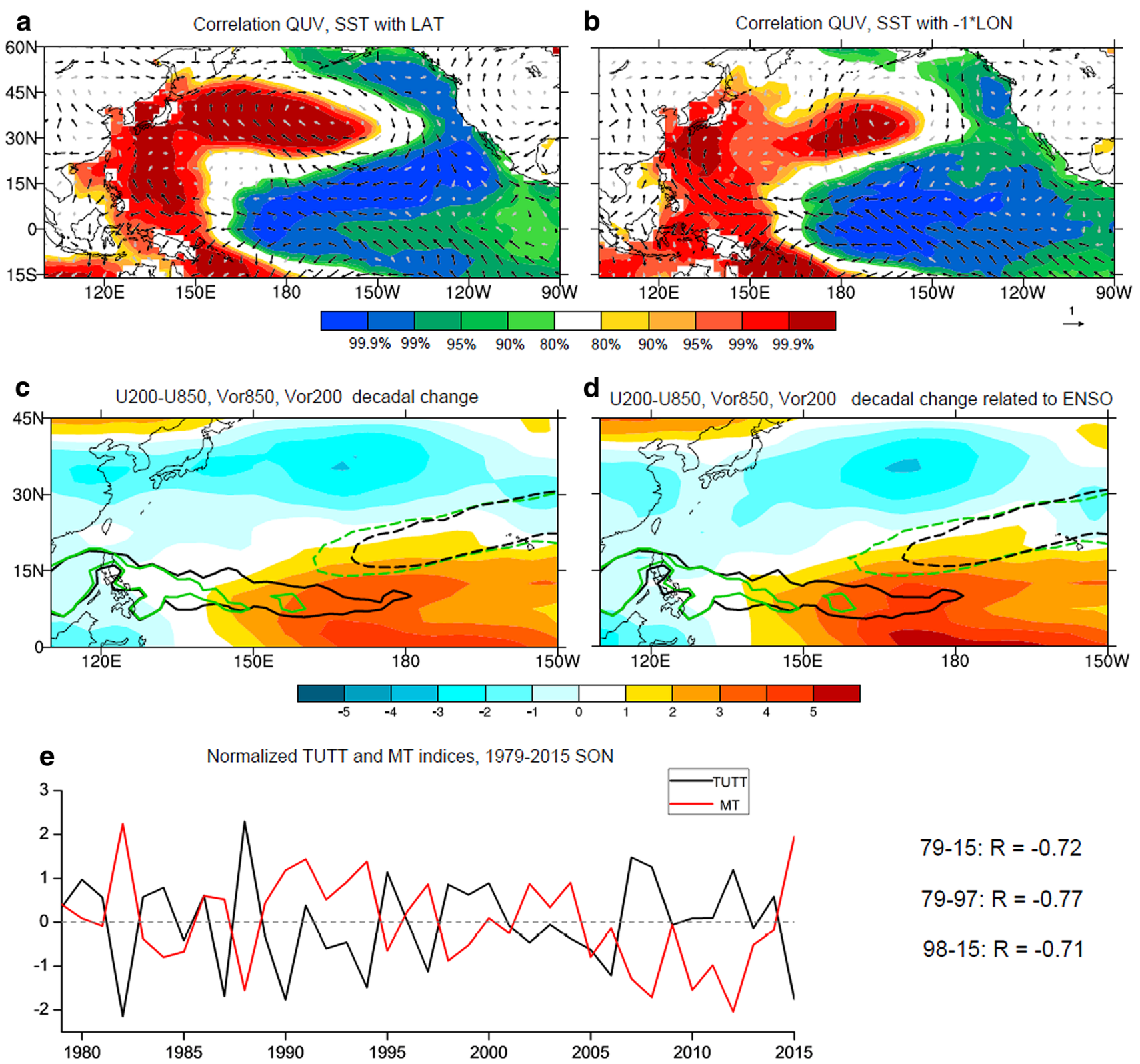

Fig. 4 Correlations of SST (shading), vertically-integrated moisture flux (QUV, vector) with a LAT and b LON shown in Fig. 3a-b during 1979-2015. Decadal changes c and ENSO-related decadal changes d of U200-U850 (shading) between 1980-1997 and 1998-2015 (1998-2015 minus 1980-1997). The climatological TUTT (dashed lines) and MT (solid lines) during 1980-1997

\section{Discussion and concluding remarks}

Hsu et al. (2014) suggested that the large decrease of WNP typhoon numbers in recent years is mainly due to the significant reduction during the late TC season. Such a reduction is significantly associated with a northwestward shift of the WNP TCLs, which lead to relative shorter durations over the ocean and thus less intense typhoons because TCs have less time and traveling distance over the WNP warm (black) and during 1998-2015 (green) are also shown in c, d. e Normalized time series of TUTT and MT, and their correlations during 1979-2015, 1979-1997 and 1998-2015. Here, the TUTT and MT indices are defined as the regional mean relative vorticity at $200 \mathrm{hPa}$ over $170^{\circ} \mathrm{E}-175^{\circ} \mathrm{W} / 12.5^{\circ} \mathrm{N}-17.5^{\circ} \mathrm{N}$ and $850 \mathrm{hPa}$ over $150^{\circ} \mathrm{E}-175^{\circ} \mathrm{E} / 10^{\circ} \mathrm{N}-15^{\circ} \mathrm{N}$ during $1979-2015$, respectively

pool for development and enhancement (e.g., Wang and Chan 2002; Wang et al. 2013; Camargo and Sobel 2005; Wu and Wang 2008; Zhao et al. 2011, 2014b; Zhao and Wu 2014). By revisiting the large-scale environment changes associated with shfting ENSO and WNP TCL during the late TC season (i.e., autumn), we unraveled in this study the potential linkages among the northwestern ward shift of WNP TCLs, east-west wards of TUTT and MT, four ENSO flavors, and the 1998 Pacific climate regime shift. Composite 
and correlation analyses of autumn WNP TCLs and Pacific SST anomalies with atmospheric features revealed several prominent features:

First, the responses of mean WNP TCLs to the four flavors of ENSO are distinct: EPW mainly favors tropical cyclogenesis over the southeastern WNP, CPW promotes enhanced tropical cyclogenesis over the central-western WNP, and a significantly northwestward shift of the mean TCL occurs during the two types of La Niña years especially for CPC. These are consistent with previous studies (e.g., Wang et al. 2013; Zhao and Wang 2016). Such diverseENSO-related TCL shifts could inevitably lead to changes in duration and traveling distance of TCs over the warm pool region and thus affect TC intensity (e.g., Wang and Chan 2002; Wu and Wang 2008; Wang et al. 2013, Hsu et al. 2014; Zhao and Wang 2016).

Second, the effects of PDO and shifting ENSO on the mean WNP TCLs are closely linked to the tacit-and-mutual configurations of the upper-level TUTT and low-level MT (Figs. 2a-d, 4a-d). Moreover, there are no significant changes in TUTT, MT, and vertical wind shear when the ENSO is in its neutral phase during the boreal autumn (Fig. A5), indirectly hinting the importance of regulating mechanisms of diverse ENSO events on TCLs via TUTT and MT.

Third, both the mean latitude and longitude of WNP TCLs experienced a sharp interdecadal variation in autumn 1998. The change in mean longitude is closely associated with four flavors of ENSO (i.e., CPC, EPC, CPW, and EPW), whereas the change in mean latitude is only sensitive to the phase (cold or warm) of ENSO but not to the type (EP or CP) of El Niño (Fig. A2). The reason for this case is likely because the change in mean latitude of the WNP TCLs is dominated by the WNP warming induced by CP La Niña events and/or the interdecadal CP La Niña-like events.

It should be noted that the tacit-and-mutual configurations between TUTT and MT always exhibit a stable and strong relationship on both interannual and interdecadal timescales (Figs. 2a-d, 4c, d); that is, a southwestward expansion of the TUTT always corresponds to a northwestward retreat of the MT, and a southeastward expansion of the MT always corresponds to a northeastward retreat of the TUTT. To further confirm this relationship, Fig. 4e shows a robust relationship between TUTT and MT, both with strong interannual variability, during 1979-2015 $(R=-0.72)$, $1979-1997(R=-0.77)$ and $1998-2015(R=-0.71)$.

Although much needs to be understood about the interrelation between the rapidly changing ENSO and large-scale environment patterns on the WNP TCLs (e.g., Hsu et al. 2014; Zhao et al. 2014b; Zhao and Wang 2016), we provide further evidence linking ENSO shift and the Pacific climate regime shift to the WNP TCLs, with an emphasis on the roles of the TUTT and MT in autumn. As the interaction between external anthropogenic forcing (i.e., increasing anthropogenic greenhouse gases) and internal natural variability continues to evolve gradually (e.g., $\mathrm{Hu}$ and Fedorov 2017), projections of more frequent extreme ENSO (Cai et al. 2014, 2015a, b), ENSO diversity (e.g., Hu et al. 2016a, b; Chen et al. 2015) and PDO modulation (e.g., Zhao and Wang 2016), as well as their resultant effects on concurrent TCL changes, are inherently uncertain. We expect to see a further TCL change over the WNP, which is closely related to the major population centers across much of eastern China, Korea and Japan, where billions of people can be affected.

Acknowledgements This research is supported by the National Postdoctoral Program for Innovative Talents (Grant BX201600039), the National Natural Science Foundation of China (Grants 41705050, 41690120, 41690121, 41690123, 41465003, and 41621064), the Scientific Research Fund of the Second Institute of Oceanography (JB1702), the National Key Scientific Research Plan of China (Grant 2013CB430300), the National Program on Global Change and AirSea Interaction (GASI-IPOVAI-04), and the Jiangsu Collaborative Innovation Center for Climate Change. Computing resources for this study were provided by the China National Supercomputer Center in Guangzhou.

Open Access This article is distributed under the terms of the Creative Commons Attribution 4.0 International License (http://creativecommons.org/licenses/by/4.0/), which permits unrestricted use, distribution, and reproduction in any medium, provided you give appropriate credit to the original author(s) and the source, provide a link to the Creative Commons license, and indicate if changes were made.

\section{References}

Bister M, Emanuel KA (2002) Low frequency variability of tropical cyclone potential intensity. 1. Interannual to interdecadal variability. J Geophys Res 107:4801

Cai W et al (2014) Increasing frequency of extreme El Niño events due to greenhouse warming. Nat Clim Change 4:111-116. https://doi.org/10.1038/nclimate2100

Cai W et al (2015a) ENSO and greenhouse warming. Nat Clim Change 5:849-859. https://doi.org/10.1038/nclimate2743

Cai W et al (2015b) Increased frequency of extreme La Niña events under greenhouse warming. Nat Clim Change 5:132-137. https://doi.org/10.1038/nclimate2492

Camargo SJ, Sobel AH (2005) Western North Pacific tropical cyclone intensity and ENSO. J Clim 18:2996-3006

Camargo SJ, Emanuel KA, Sobel AH (2007) Use of a genesis potential index to diagnose ENSO effects on tropical cyclone genesis. J Clim 20:4819-4834

Camargo SJ, Wheeler MC, Sobel AH (2009) Diagnosis of the MJO modulation of tropical cyclogenesis using an empirical index. $\mathrm{J}$ Atmos Sci 66:3061-3074

Chan JCL (2000) Tropical cyclone activity over the western North Pacific associated with El Niño and La Niña events. J Clim 13:2960-2972

Chan JCL (2006) Comment on "Changes in tropical cyclone number, duration, and intensity in a warming environment". Science 311:1713. https://doi.org/10.1126/science. 1121522 
Chen D et al (2015) Strong influence of westerly wind bursts on El Niño diversity. Nat Geosci 8:339-345. https://doi.org/10.1038/ ngeo2399

Choi Y, Ha KJ, Ho C-H, Chung CE (2015) Interdecadal change in typhoon genesis condition over the western North Pacific. Clim Dyn 45:3243. https://doi.org/10.1007/s00382-015-2536-y

Choi J-W, Cha Y, Kim T, Kim H-D (2017) Interdecadal variation of tropical cyclone genesis frequency in late season over the western North Pacific. Int J Climatol. https://doi.org/10.1002/ joc.5090 (in press)

Dee DP et al (2011) The ERA-Interim reanalysis: configuration and performance of the data assimilation system. Q J R Meteorol Soc 137:553-597. https://doi.org/10.1002/qj.828

Deng K, Yang S, Ting M, Hu C, Lu M (2017) Variations of midPacific trough and their relations to the Asian-Pacific-North American climate: roles of tropical sea surface temperature and Arctic sea ice. J Clim. https://doi.org/10.1175/JCLID-17-0064.1 (Accepted, nearing early-online and in press)

Emanuel KA (1995) Sensitivity of tropical cyclones to surface exchange coefficients and a revised steady-state model incorporating eye dynamics. J Atmos Sci 52:3969-3976

Emanuel KA (2005) Increasing destructiveness of tropical cyclones over the past 30 years. Nature 436:686-688

Emanuel KA, Nolan D (2004) Tropical cyclone activity and global climate. 26th Conference on Hurricanes and Tropical Meteorology, Miami, FL. American Meteorological Society, pp 240-241

Ferreira RN, Schubert WH (1999) The role of tropical cyclones in the formation of tropical upper-tropospheric troughs. J Atmos Sci 56:2891-2907

Fitzpatrick PJ, Knaff JA, Landsea CW, Finley SV (1995) A systematic bias in the aviation model's forecast of the Atlantic tropical uppertropospheric trough: implications for tropical cyclone forecasting. Weather Forecast 10:3-446

Gray WM (1979) Hurricanes: their formation, structure and likely role in the tropical circulation. Meteorology over the Tropical Oceans. R Meteorol Soc: $155-218$

He H, Yang J, Gong D, Mao R, Wang Y, Gao M (2015) Decadal changes in tropical cyclone activity over the western North Pacific in the late 1990s. Clim Dyn 45:3317-3329. https://doi. org/10.1007/s00382-015-2541-1

He H, Yang J, Wu L, Gong D, Wang B, Gao M (2017) Unusual growth in intense typhoon occurrences over the Philippine Sea in September after the mid-2000s. Clim Dyn 48:1893-1910. https://doi. org/10.1007/s00382-016-3181-9

Hong C-C, Li T, Wu Y-K, Chang C-C (2014) The climate regime shift over the Pacific during 1996/1997. Clim Dyn 43(1-2):435-446

Hong C-C, Wu YK, Li T (2016) Influence of climate regime shift on the interdecadal change in tropical cyclone activity over the Pacific Basin during the middle to late 1990s. Clim Dyn 47:25872600. https://doi.org/10.1007/s00382-016-2986-x

Hsu PC, Chu PS, Murakami H, Zhao X (2014) An abrupt decrease in the late-season typhoon activity over the western North Pacific. J Clim 27:4296-4312. https://doi.org/10.1175/JCLI-D-13-00417.1

Hu S, Fedorov AV (2017) The extreme El Niño of 2015-2016 and the end of global warming hiatus. Geophys Res Lett 44:3816-3824. https://doi.org/10.1002/2017GL072908

$\mathrm{Hu} \mathrm{C}$ et al (2016a) Reinspecting two types of El Niño: a new pair of Niño indices for improving real-time ENSO monitoring. Clim Dyn 47:4031-4049. https://doi.org/10.1007/s00382-016-3059-x

Hu C, Yang S, Wu Q, Li Z, Chen J, Deng K, Zhang T, Zhang C (2016b) Shifting El Niño inhibits summer Arctic warming and Arctic seaice melting over the Canada Basin. Nat Commun 7:11721. https:// doi.org/10.1038/ncomms11721

Huang B, Banzon VF, Freeman E, Lawrimore J, Liu W, Peterson TC, Smith TM, Thorne PW, Woodruff SD, Zhang H-M (2015) Extended reconstructed sea surface temperature version 4
(ERSST.v4). Part I: upgrades and intercomparisons. J Clim 28:911-930. https://doi.org/10.1175/JCLI-D-14-00006.1

Huang R, Huangfu J, Wu L, Feng T, Chen G (2016) Research on the interannual and interdecadal variabilities of the monsoon trough and their impacts on tropical cyclone genesis over the western North Pacific. J Tropic Meteorol 32:767-785 (in Chinese)

Huangfu J, Huang R, Chen W, Feng T, Wu L (2017) Interdecadal variation of tropical cyclone genesis and its relationship to the monsoon trough over the western North Pacific. Int J Climatol 37:3587-3596. https://doi.org/10.1002/joc.4939

Jiang X, Zhao M, Waliser DE (2012) Modulation of tropical cyclones over the eastern Pacific by the intraseasonal variability simulated in an AGCM. J Clim 25:6524-6538

Jin C-S, Ho C-H, Kim J-H, Lee D-K, Cha D-H, Yeh SW (2013) Critical role of northern off-equatorial sea surface temperature forcing associated with Central Pacific El Niño in more frequent tropical cyclone movement toward East Asia. J Clim 26:2534-2545. https://doi.org/10.1175/JCLI-D-12-00287.1

Jo H-S, Yeh S-W, Lee S-K (2015) Changes in the relationship in the SST variability between the tropical Pacific and the North Pacific across the 1998/1999 regime shift. Geophys Res Lett 42:71717178. https://doi.org/10.1002/2015GL065049

Kalnay E et al (1996) The NCEP/NCAR 40-year reanalysis project. Bull Am Meteorol Soc 77:437-471

Kamahori HN, Yamazaki N, Mannoji N, Takahashi K (2006) Variability in intense tropical cyclone days in the western North Pacific. SOLA 2:104-107. https://doi.org/10.2151/sola.2006-027

Kao H-Y, Yu J-Y (2009) Contrasting eastern-Pacific and centralPacific types of ENSO. J Clim 22:615-632. https://doi.org/10. 1175/2008JCLI2309.1

Kelley WE Jr, Mock DR (1982) A diagnostic study of upper tropospheric cold lows over the western North Pacific. Mon Weather Rev 110:471-480

Kim HM, Webster PJ, Curry JA (2009) Impact of shifting patterns of Pacific Ocean warming on North Atlantic tropical cyclones. Science 325:77-80

Kim HM, Webster PJ, Curry JA (2011) Modulation of North Pacific tropical cyclone activity by three phases of ENSO. J Clim 24:1839-1849

Knutson TR, Tuleya RE, Kurihara Y (1998) Simulated increase of hurricane intensities in a $\mathrm{CO}_{2}$-warmed climate. Science 279:1018-1021

Knutson TR, McBride JL, Chan JCL, Emanuel K, Holland G, Landsea C, Held I, Kossin JP, Srivastava AK, Sugi M (2010) Tropical cyclones and climate change. Nat Geosci 3:157-163

Kobayashi S et al (2015) The JRA-55 Reanalysis: general specifications and basic characteristics. J Meteorol Soc Jpn 93:5-48

Kug JS, Jin F-F, An SI (2009) Two types of El Niño events: cold tongue El Niño and warm pool El Niño. J Clim 22:1499-1515

Lander MA (1994) An exploratory analysis of the relationship between tropical storm formation in the western North Pacific and ENSO. Mon Weather Rev 122:636-651

Landsea CW, Franklin JL (2013) Atlantic hurricane database uncertainty and presentation of a new database format. Mon Weather Rev 141:3576-3592

Lin I-I, Chan JCL (2015) Recent decrease in typhoon destructive potential and global warming implications. Nat Commun 6:7182. https://doi.org/10.1038/ncomms8182

Liu KS, Chan JCL (2013) Inactive period of western North Pacific tropical cyclone activity in 1998-2011. J Clim 26:2614-2630

Liu W, Huang B, Thorne PW, Banzon VF, Zhang H-M, Freeman E, Lawrimore J, Peterson TC, Smith TM, Woodruff SD (2015) Extended reconstructed sea surface temperature version 4 (ERSST.v4): Part II. Parametric and structural uncertainty estimations. J Clim 28:931-951. https://doi.org/10.1175/ JCLI-D-14-00007.1 
Molinari J, Vollaro D (2013) What percentage of western North Pacific tropical cyclones form within the monsoon trough? Mon Weather Rev 141:499-505

Murakami H, Wang B (2010) Future change of North Atlantic tropical cyclone tracks: projection by a $20-\mathrm{km}$-mesh global atmospheric model. J Clim 23:2699-2721. https://doi.org/10.1175/2 010JCLI3338.1

Rayner NA, Parker DE, Horton EB, Folland CK, Alexander LV, Rowell DP, Kent EC, Kaplan A (2003) Global analyses of sea surface temperature, sea ice, and night marine air temperature since the late nineteenth century. J Geophys Res 108:4407. https://doi.org/10.1029/2002JD002670

Ren H-L, Jin F-F (2011) Niño indices for two types of ENSO. Geophys Res Lett 38:L04704. https://doi. org/10.1029/2010GL046031

Sardeshmukh PD, Hoskins BJ (1988) The generation of global rotational flow by steady idealized tropical divergence. J Atmos Sci 45:1228-1251

Song J-J, Wang Y, Wu L (2010) Trend discrepancies among three best track data sets of western North Pacific tropical cyclones. J Geophys Res 115:D12128. https://doi.org/10.1029/2009JD013058

Wang B, Chan JCL (2002) How strong ENSO events affect tropical storm activity over the western North Pacific. J Clim 13:1517-1536

Wang X, Liu H (2016) PDO modulation of ENSO effect on tropical cyclone rapid intensification in the western North Pacific. Clim Dyn 46:15-28. https://doi.org/10.1007/s00382-015-2563-8

Wang C, Wu L (2016) Interannual shift of the tropical upper-tropospheric trough and its influence on tropical cyclone formation over the western North Pacific. J Clim 29:4203-4211. https://doi. org/10.1175/JCLI-D-15-0653.1

Wang C, Li C, Mu M, Duan W (2013) Seasonal modulations of different impacts of two types of ENSO events on tropical cyclone activity in the western North Pacific. Clim Dyn 40:2887-2902. https://doi.org/10.1007/s00382-012-1434-9

Webster PJ, Holland GJ, Curry JA, Chang HR (2005) Changes in tropical cyclone number, duration, and intensity in a warming environment. Science 309:1844-1846

Wu L, Wang B (2008) What has changed the proportion of intense hurricanes in the last 30 years? J Clim 21:1432-1439. https://doi. org/10.1175/2007JCLI1715.1

Wu L, Zhao H (2012) Dynamically derived tropical cyclone intensity changes over the western North Pacific. J Clim 25:89-98

Wu L, Wang B, Geng S (2005) Growing typhoon influence on East Asia. Geophys Res Lett 32:L18703. https://doi. org/10.1029/2005GL022937

Wu L, Wen Z, Huang R, Wu R (2012) Possible linkage between the monsoon trough variability and the tropical cyclone activity over the western North Pacific. Mon Weather Rev 140:140-150. https://doi.org/10.1175/MWR-D-11-00078.1

Wu L, Wang C, Wang B (2015) Westward shift of western North Pacific tropical cyclogenesis. Geophys Res Lett 42:1537-1542. https://doi.org/10.1002/2015GL063450

Yu J-Y, Kim ST (2010) Identification of central-Pacific and easternPacific types of ENSO in CMIP3 models. Geophys Res Lett 37:L15705

Zhang W, Jin F-F, Turner A (2014) Increasing autumn drought over southern China associated with ENSO regime shift. Geophys Res Lett 41:4020-4026. https://doi.org/10.1002/2014GL060130

Zhao H, Wang C (2016) Interdecadal modulation on the relationship between ENSO and typhoon activity during the late season in the western North Pacific. Clim Dyn 47:315-328. https://doi. org/10.1007/s00382-015-2837-1

Zhao H, Wu L (2014) Inter-decadal shift of the prevailing tropical cyclone tracks over the western North Pacific and its mechanism study. Meteorol Atmos Phys 125:89-101

Zhao H, Wu L (2017) Modulation of convectively coupled equatorial Rossby wave on the western North Pacific tropical cyclones activity. Int J Climatol. https://doi.org/10.1002/joc.5220 (in press)

Zhao H, Wu L, Zhou W (2010) Assessing the influence of ENSO on tropical cyclone prevailing tracks in the western North Pacific. Adv Atmos Sci 27:1-11

Zhao H, Wu L, Zhou W (2011) Interannual changes of tropical cyclone intensity in the western North Pacific. J Meteorol Soc Jpn 89:243-253

Zhao H, Chu PS, Hsu PC, Murakami H (2014a) Exploratory analysis of extremely low tropical cyclone activity during the late-season of 2010 and 1998 over the western North Pacific and the South China Sea. J Adv Model Earth Syst 06:1141-1153

Zhao H, Wu L, Wang R (2014b) Decadal variations of intense tropical cyclones over the western North Pacific during 1948-2010. Adv Atmos Sci 31:57-65

Zhao H, Jiang X, Wu L (2015a) Modulation of Northwest Pacific tropical cyclone genesis by the intraseasonal variability. J Meteorol Soc Jpn 93:1

Zhao H, Yoshida R, Raga GB (2015b) Impact of the Madden-Julian oscillation on western North Pacific tropical cyclogenesis associated with large-scale patterns. J Appl Meteorol Climatol 54:1413-1429

Zhao H, Raga GB, Klotzbach PJ (2017) Impact of the boreal summer quasi-biweekly oscillation on Eastern North Pacific tropical cyclone activity. Int J Climatol. https://doi.org/10.1002/joc.5250 (in press) 